\title{
PHYSIOLOGICAL, BIOCHEMICAL AND PHYLOGENETIC CHARACTERIZATION OF EXTREMELY HALOPHILIC BACTERIA ISOLATED FROM KHEWRA MINE, PAKISTAN
}

\author{
LEENA, M. C. - AAMER, A. S. - ABDUL, H. - FARIHA, H.* \\ Department of Microbiology, Quaid-i-Azam University \\ Islamabad 44000, Pakistan \\ *Corresponding author \\ e-mail: farihahasan@yahoo.com; phone: +92-51-9064-3065 \\ (Received $3^{\text {rd }}$ Aug 2017; accepted $30^{\text {th }}$ Nov 2017)
}

\begin{abstract}
Microflora entrapped in the salt deposits of Khewra salt mine, Pakistan has adapted to extreme conditions and nutrient scarcity to survive. Due to assumption that halophilic archaea dominate hypersaline environments, bacteria have often remained unexplored. The reports on extremely halophilic bacteria indigenous to Khewra mine are quite limited resulting in largely unexplored biodiversity of the salt mine. Here we attempted to fill that gap by isolating eight halophilic bacteria, out of which four extremely halophilic bacteria were selected for physiological, biochemical and molecular characterization. The phylogenetic characterization inferred through comparative partial 16S rRNA sequences identified these strains as HSL1-Oceanobacillus onchorhynci subsp. Incaldanensis, HSL4Staphylococcus lentus, HSL6-Bacillus endophyticus and HSL7-Bacillus aquimaris. These isolates could tolerate a wide range of temperatures $\left(15-45^{\circ} \mathrm{C}\right), \mathrm{pH}(5-9)$ and survived up to $16 \% \mathrm{NaCl}$ concentration. This tolerance is due to the stability of their enzymes. Enzyme assays revealed a substantial amount of production of protease, amylase, lipase, xylanase, urease, gelatinase, cellulose, and DNase. Conclusively, isolation and characterization of the extremely halophilic bacteria from Khewra mine indicated their important ecological role and contribution towards the microbial diversity. The ability to produce extreme-enzymes also established the potential of the isolates as valuable resources for significant biotechnological applications.
\end{abstract}

Keywords: halophiles, halophilic bacteria, halo-enzymes, phylogeny, hypersaline environments

\section{Introduction}

Extremophiles are those organisms that can survive in intense environments. Such environments include high and low extremes of temperature, $\mathrm{pH}$, pressure, nutrients, water content, salt content, heavy metal toxicity, organic solvent toxicity, and radiations. Prokaryotes usually dominate the regions concentrated with salts. Habitats such as soda lakes, brines and coastal lagoons are inhabited by fewer life forms but have a significant presence of halophiles. The careful study of halophiles evolutionary patterns also helps to understand, the evolution of the environment.

Halophiles are classified as slightly $(0.2-5 \%)$, moderately $(5-16 \%)$ and extremely (16-30\%) halophilic species depending upon their growth response to $\mathrm{NaCl}$ concentration (Kushner, 1978). Halotolerant bacteria are non-halophilic microorganisms that can tolerate high salt concentrations, i.e., above $15 \%$ of $\mathrm{NaCl}$, and can also survive without $\mathrm{NaCl}$ (Kushner, 1985; Oren, 2008). Halophilic adaptation to high salinity and in some cases extreme temperatures and radiation is due to the evolution of their biochemical and physiological functions. The protein chemistry of halo-enzymes enables them to exhibit unique attributes, which equip them to thrive in variable habitats (Burg, 2003). Extremophiles selectively thrive under harsh environmental conditions by developing unique adaptive strategies including synthesis of bioactive compounds such 
as compatible solutes, bacteriorhodopsins, extreme-enzymes, and bio-surfactants (Donio et al., 2013). In accordance with BCC reports of 2011, the enzyme industry, especially when it comes to commercial programs, experienced an increase of US\$ 3.3 million from the previous year. This kind of demand from the customers motivates the search for enzymes that can withstand the extreme hostile conditions of the industrial procedures. Currently, the efficiency of most of the enzymes decreases when met with the extreme temperature and acidity (Cojoc et al., 2009; Kakhki et al., 2011). Halophiles have been continuously found with an unrivaled capacity to synthesize bioactive secondary metabolites with potent biological activities, which establish their remarkable potential in commercial applications (Vahed et al., 2011).

Pakistan is unique in its biodiversity and blessed with diverse extreme environments. Remote areas of Pakistan are endowed with many thermal springs, salt mines, and many glacial areas. Khewra salt mine, Pakistan is considered as the largest salt mine in the world based on area, second only to Wieliczka Salt mine in Poland (Sameeni, 2009). Geologists placed the age of Khewra mine to 600 million years. Paleontologists and stratigraphic constraints suggested that the tectonic movements due to conventional currents generated by the core of the earth commenced the formation of rift basins along the middle eastern side of Gondwanaland in the latest Precambrian. The continental drift theory suggests that Indo-Pak made its incredible journey away from Antarctica towards Asia approximately 180 million years ago, covering a distance of about 5500 miles (Redfern, 2001). During this time, marine deposits swept across the Middle East in the late lower and middle Cambrian period (Husseini and Husseini, 1990). Consequently, evaporates started precipitating salt; forming salt deposits in the form of Khewra salt mine. However, the microflora of these areas is yet to be uncovered and those species, which have been isolated, are yet to be validated by the ecological ministry of Pakistan. A few reports have been presented on halophilic diversity from salt ranges of Khewra, which were mostly focused on the isolation of moderately halophilic bacteria such as Halomonas magadiensis, Virgibacillus species (Akhtar et al., 2008).

\section{Objective}

Interest in the extremophile diversity has grown over the last decade as it may support the theory that such extreme conditions have been present on the primitive earth. A similar logical argument underlies the search for life forms outside the planet earth (Akhtar et al., 2008). The chronological history of biodiversity of microbes entrapped in the rock salt deposits of Khewra mine over a period of millions of years suggested them to have conserved DNA bases as of their ancestors. It is generally assumed that hypersaline environments are dominated by halophilic archaea, whereas bacteria have often been considered not relevant to high saline environments and hence ignored. A diversity of halophilic bacteria could enlighten us about their role in the maintenance of such high saline environments. Also, the adaptations of halophilic bacteria to harsh conditions can help us understand about their resemblance with the organisms which were prevalent on the primitive earth. These interesting questions clearly justify the motivation of current exploration of isolating and characterizing extremely halophilic bacteria from the ancient rock salt deposits of Khewra salt mine and screening their highly stable enzymes for potential commercial applications.

Hence, this presentation reports on novel studies performed on extremely halophilic bacteria from the rock salt deposits, and saline soils of Khewra. These studies include a 
screening of bacteria for valuable commercial halo-enzymes, development of growth patterns of bacteria with respect to different physiological parameters, and to track the evolutionary pattern of these bacteria based on their phylogenetic resemblance with their ancestors.

\section{Materials and methods}

\section{Site description}

In South Asia, the Khewra salt mines are the oldest salt mines situated at the foothills of the Salt Range about $288 \mathrm{~m}$ above the sea level from where salt has been mined since $320 \mathrm{BC}$. The crystals are colored light pink with variations of white and red famously referred to as Himalayan pink salt. It is considered to be $98 \%$ pure. Salt and brine samples were collected from the Khewra salt mine. Location coordinates were noted by GPS tracker as $32^{\circ} 39^{\prime} 0^{\prime \prime} \mathrm{N}, 7^{\circ} 1^{\prime} 0^{\prime \prime E}$ (Fig. 1). The $\mathrm{pH}$ (measured by $\mathrm{pH}$ strips) and temperature (measured by a laboratory thermometer) of the brine were first noted at the sampling site, and later $\mathrm{pH}$ was measured under laboratory conditions by a $\mathrm{pH}$ meter (Sartorius professional meter PP15). The $\mathrm{pH}$ of the brine was 7.1 and temperature was $25^{\circ} \mathrm{C}$ at the time of sampling. The salinity of brine was measured by using a hand-held refractometer as 30\%, and the Total Dissolved Solids were calculated as $32 \%$.
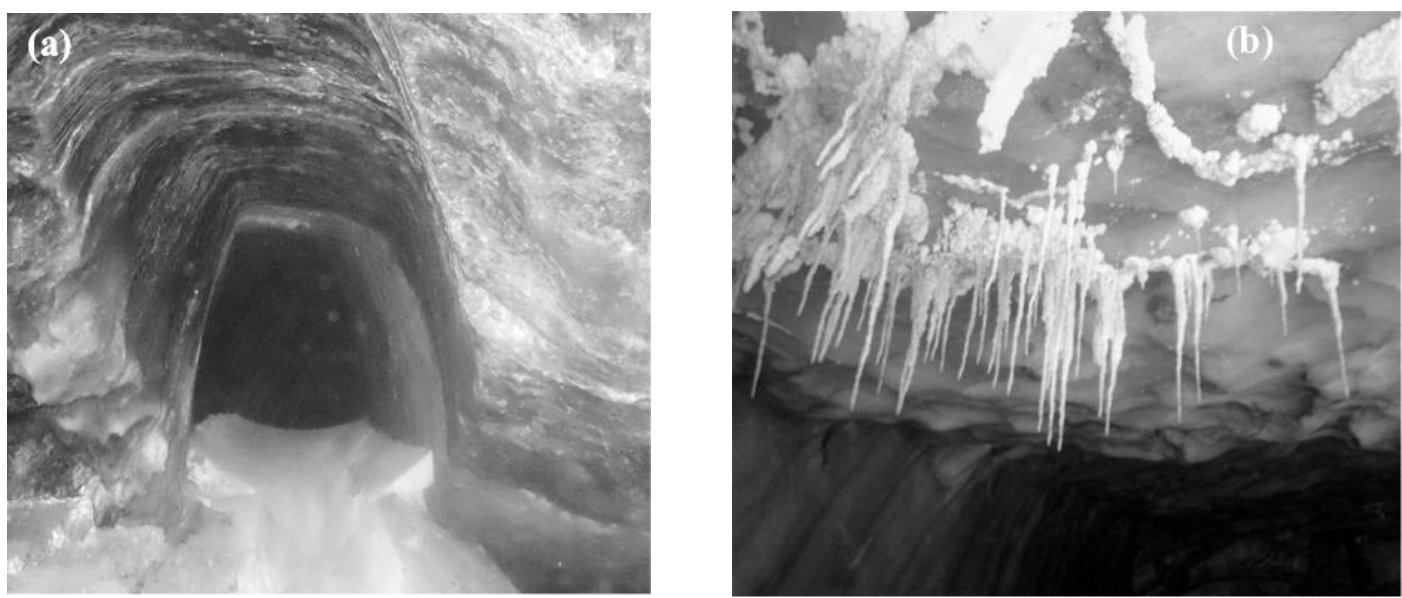

Figure 1. Selected photos from Khewra salt mine. a) Khewra's red Himalayan rock salt. b) Salt deposits in Khewra Mine

\section{Analysis of brine obtained from Khewra mine}

The analysis of sulfates, chlorides, phosphates and bicarbonates in brine was done using Spectroquant (Pharo 100 Spectroquant ${ }^{\circledR}$ Merck, Germany) using respective protocols from Standard Methods for the Examination of Water and Wastewater by (APHA), American Public Health Association (Table 2).

\section{Isolation of extremely halophilic bacteria}

Isolation was done from both brine and salt samples using serial dilution method up to 15 folds of dilution. The samples were inoculated on nutrient agar plates with $3 \%$ of $\mathrm{NaCl}$ concentration using Spread plate method. After 48-72 h of incubation, individual 
colonies were picked out and purified using three rounds of streaking on a nutrient agar plate.

\section{Media and culturing}

Most of the reagents and chemicals used in this study were of analytical grade and obtained from BDH (Dorset, England), Sigma- Aldrich (St. Louis, MA, USA), E Merck (Darmstadt, Germany), Difco Laboratories (Detroit, USA), AVACADO research chemicals Ltd (London, UK). Eight distinct colonies names as (HSL1, HSL2, HSL3, HSL4, HSL5, HSL6, HSL7, and HSL8) from salt and water samples collected from Khewra salt mine, were isolated for the present study. The bacterial cultures were maintained on a nutrient agar medium, containing $16 \% \mathrm{NaCl}$. Extremely halophilic were screened out by sub-culturing on the nutrient agar plates with varying salt concentrations, ranging from 3 to $22 \%$ and incubated for $24-72 \mathrm{~h}$. Out of eight, four extreme halophilic strains (HSL1, HSL4, HSL6, and HSL7) that grew above $16 \% \mathrm{NaCl}$ concentration were selected for further research.

\section{Morphological and biochemical studies of halophilic strains}

The bacterial colonies were distinguished on the basis of size, pigmentation, form, margin and elevation. These were also characterized on the basis of Gram's staining, cell morphology, and motility under a microscope. Four selected bacterial strains were characterized biochemically according to Bergey's Manual of Determinative Bacteriology by Holt et al., 1994. Following basic tests were performed: Triple sugar iron (TSI) test, Catalase test, SIM (Sulfide, Indole, Motility) test, $\mathrm{H}_{2} \mathrm{~S}$ test, Citrate utilization test, Oxidase test, and Urease test.

\section{Physiological properties of halophilic bacteria}

Growth optimization was carried out at various temperatures and $\mathrm{pH}$, i.e., $15-50^{\circ} \mathrm{C}$ and $\mathrm{pH} 4.0-9.0$, respectively. The growth was observed both qualitatively (nutrient agar plates) and quantitatively (nutrient broth) over the period of seven days. By taking OD at $650 \mathrm{~nm}$ at regular time intervals, we monitored the growth at regular time intervals quantitatively using Agilent 8453 UV-visible Spectrophotometer. All the optimization experiments were done in triplicates, and the average value of each reading was plotted for accuracy with error bars indicating standard deviation. All data is presented as a standard error of the mean. The growth patterns of strains were also tested on varying salinity by growing them on nutrient agar plates having various salt ranges (0-22\%). Also, the growth of strains on salts other than $\mathrm{NaCl}$ was studied by growing them on plates of nutrient agar supplemented with $3 \%$ of each salt for 24-48 h. The salts used were $\mathrm{KCl}, \mathrm{CaCO}_{3}, \mathrm{NH}_{4} \mathrm{Cl}, \mathrm{MgSO}_{4}$, and $\mathrm{BaCl}_{2}$.

\section{Screening of enzyme activity}

To establish the potential of these strains in industrial applications, these strains were screened for the production of amylase, protease, lipase, DNase, cellulase, and gelatinase. Nutrient agar plates containing $1.5 \%$ of starch, casein, tween 80 and cellulose as substrates were separately streaked with halophilic strains to determine the production of amylase, protease, and lipase and cellulase activity respectively. DNase agar medium was used for DNase test. Zones of hydrolysis around colonies indicated a 
positive activity of DNase and lipase enzymes. Iodine solution (2\%) was poured on starch plates for $5 \mathrm{~min}$. Clear halos indicated positive results. Cellulose plates were first stained with $0.5 \%$ Congo red for $5 \mathrm{~min}$ and then de-stained with $1 \mathrm{M} \mathrm{NaCl}$. Clear halos indicated cellulase activity. Protease activity was determined by pouring glacial acetic acid on the streaked plates followed by the production of clear zones. For gelatinase production, strains were inoculated in media having following composition $(\mathrm{g} / \mathrm{L})$ : peptone 5 , beef extract 3 , gelatin $120, \mathrm{NaCl} 5$. Liquefaction of gelatin indicated a positive result.

\section{Enzyme assays}

To further understand the specific activity of amylase and protease, enzyme assays were performed. The proteolytic activity was measured by following the technique developed by Kunitz (1965) where production of extracellular protease can be determined by observing the split contents of casein dissolved in 5\% TCA solution. Controls were prepared in the same way except that $2.25 \mathrm{ml}$ TCA was added before incubation. The specific activity of protease was determined by measuring the amount of tyrosine released per $\mathrm{ml} / \mathrm{min}$ under the conditions of the assay at $\mathrm{OD}_{280} \mathrm{~nm}$. Lipase assay was performed as described by Lesuisse et al. (1993) and the specific activity was taken at $\mathrm{OD}_{420} \mathrm{~nm}$. Amylase assay was performed as described by Bernfeld (1955) with specific activity measured at $\mathrm{OD}_{540} \mathrm{~nm}$ of glucose released per $\mathrm{ml} / \mathrm{min}$ under the assay conditions.

\section{Genomic DNA extraction and PCR}

For molecular characterization, first, the genomic DNA was extracted using ethanol precipitation method (Delbes et al., 2000), with slight modification. The genomic DNA is confirmed by gel electrophoresis by running it on $1 \%$ gel in $0.5 \mathrm{X}$ TBE buffer. Gel images were observed by Bio-Rad gel documentation system. Using the universal primers 8F-5'AGAGTTTGATCCTGGCTCAG and 1492R5'AAGTCGTAACAAGGTAACC, 1500bp regions of 16S rRNA gene of the extracted DNA was amplified. The PCR products were then sent to Macrogen, Inc., Seoul, Korea for sequencing.

\section{Phylogenetic analysis using $16 \mathrm{~S}$ rRNA}

Sequenced $16 \mathrm{~S}$ rRNA genes data was assembled manually (http://www.ncbi.nlm.nih.gov/blast/bl2seq/wblast2.cgi) utilizing Blast 2 sequences (Tatusova and Madden, 1999). To determine sequence of a clone, the sequences of both the strands were separately compiled and then aligned to each other with their complementary region. A consensus sequence was originated by aligning multiple sequences of every clone belonging to the same component of individual isolates by using ClustalW (Thompson et al., 1994). The sequences of genomic components were aligned in ClustalW Sequence Alignment program using IUB matrix for DNA alignments in the Molecular Evolutionary Genetics Analysis Program (MEGA) version 6. Neighbor-Joining (NJ) analysis was carried out using Maximum Compositelikelihood model with uniform rates among the sites; the 1000 bootstrap replicates were used to evaluate the significance of generated tree. 


\section{Results}

\section{Morphological and biochemical characterization}

Four extreme halophilic strains (HSL1, HSL4, HSL6, and HSL7) were characterized. Based on colony morphology, Gram staining and Biochemical tests, following basic identification were achieved. HSL1 strain was gram-negative rods with creamy, waxy colony and hard texture. This colony was flat with undulated margins. HSL1 strain was motile. It showed positive results for catalase and oxidase and negative results for urease and indole production. This strain was able to ferment glucose. HSL4 strain was gram-positive cocci in the form of tetrads having whitish, smooth and entire colony with slightly raised surface and round margins. This strain was motile, catalase positive, oxidase, urease, and indole negative. It was able to ferment lactose. HSL6 strain was gram-positive rods displaying beige color colony having irregular, lobate margins and hard, flat surface. This strain was non-motile, indole, catalase and urease negative. It was oxidase positive and able to ferment glucose. HSL7 strain is gram-positive rods having smooth, orange colored, having round margins. The colony displayed convex elevation. This strain was motile, catalase positive, urease, oxidase and indole negative and able to ferment lactose (Table 1).

Table 1. Characteristics of the sampling site

\begin{tabular}{c|c|c|c|c}
\hline \multirow{2}{*}{ Characteristics } & \multicolumn{5}{|c}{ Isolates } \\
\cline { 2 - 5 } Form & HSL1 & HSL4 & HSL6 & HSL7 \\
\hline Elevations & Irregular, waxy, hard & $\begin{array}{c}\text { Entire, smooth, } \\
\text { mucoid } \\
\text { Slightly raised }\end{array}$ & Irregular, hard & $\begin{array}{c}\text { Smooth, mucoid, } \\
\text { hard } \\
\text { Convex }\end{array}$ \\
Margins & Flat & Flat & Round \\
Cell shape & Undulate & Mucoid & Lobate & Rods \\
Gram stain & Negative & Cocci & Rods & Positive \\
Catalase & + & Positive & Positive & + \\
Oxidase & + & + & - & - \\
Motility & + & - & + & + \\
Citrate utilization & - & + & - & - \\
Urease test & - & - & + & - \\
Lactose & + & - & - & + \\
fermentation & + & + & - & + \\
Protease & - & + & - & + \\
Amylase & - & - & + & + \\
DNase & - & - & - & - \\
Gelatinase & - & + & - & - \\
Lipase & - & - & - & - \\
Cellulase & - & - & & -
\end{tabular}

\section{Qualitative screening for enzyme activity}

HSL1 did not hydrolyze starch, gelatin, cellulose, and casein and also shows negative results for and Tween 80 and DNase. HSL4 did not hydrolyze starch (amylase), gelatin 
(gelatinase) and is negative for DNase and Tween 80 (lipase). But it showed positive results for (protease) casein and (cellulase) cellulose hydrolysis. HSL6 showed negative results for gelatin, casein and cellulose hydrolysis and is also negative for DNase and Tween 80. It only showed a positive result for amylase production. HSL7 displayed positive results for amylase, protease, DNase, but showed negative results for Tween 80 , cellulose and gelatin hydrolysis (Table 1).

\section{Physiological analysis of growth of halophilic bacteria}

HSL4 showed maximum tolerance at $22 \% \mathrm{NaCl}$ followed by HSL1, HSL7, and HSL6 at $16 \%$ salt concentration. Isolate HSL6, however, showed slight growth at $16 \%$ and the rest of the strains showed no growth above $16 \% \mathrm{NaCl}$. The strains HSL1, HSL4, HSL6, and HSL7, showed significant growth on the salts of chlorides, sulfates, and carbonates displaying their tolerance for all of these salts, besides $\mathrm{NaCl}$ (Table 2).

Table 2. Morphological and biochemical characteristics of isolated strains along with physicochemical features of sampling site and samples

\begin{tabular}{c|c|c|c|c}
\hline & Samples & Temperature & pH & $\begin{array}{c}\text { Salinity } \\
\text { (refractometer) }\end{array}$ \\
\hline $\begin{array}{c}\text { Khewra salt mine } \\
\left(32^{\circ} 39^{\prime} 0 " \mathrm{~N}, 73^{\circ} 1^{\prime} 0 " \mathrm{E}\right)\end{array}$ & Brine, salt & $25^{\circ} \mathrm{C}$ & 7.2 & $30 \%$ \\
\hline $\begin{array}{c}\text { Concentration of salts in } \\
\text { brine } \\
(\mathrm{mg} / \mathrm{l})\end{array}$ & Sulfates & Chlorides & Bicarbonates & Phosphates \\
\cline { 2 - 5 } & 9400 & 2202.42 & 200 & 0.15 \\
\hline
\end{tabular}

\section{Optimization of growth}

\section{Effect of $p H$ on growth of bacteria}

Quantitative and qualitative analysis of the effect of $\mathrm{pH}$ on growth of strains after $24 \mathrm{~h}$, depicted that isolate HSL1 tolerated and survived at $\mathrm{pH}$ ranging from 5 to 9 but showed maximum growth at $\mathrm{pH}$ 7. Isolate HSL4 tolerated $\mathrm{pH}$ ranging from 5-9 but showed maximum growth at $\mathrm{pH}$ 7. Isolate HSL6 tolerated at $\mathrm{pH}$ 5-9 but showed maximum growth at $\mathrm{pH}$ 6. Isolate HSL7 showed maximum growth at $\mathrm{pH} 8$ but were not able to tolerate $\mathrm{pH}$ 5-9 (Fig. 2).

\section{Effect of temperature on growth of bacteria}

Quantitative and qualitative observations of the growth of strains at different temperatures were performed for 4 days. Isolate HSL1 can tolerate and survive at $15-$ $45^{\circ} \mathrm{C}$ but showed maximum activity at $35^{\circ} \mathrm{C}$. Significant growth was observed at $15^{\circ} \mathrm{C}$ and $45^{\circ} \mathrm{C}$ after $2-3$ days. Isolate HSL4 survived at temperature $15-45^{\circ} \mathrm{C}$ but showed maximum activity at $35^{\circ} \mathrm{C}$. Significant growth at all temperatures can be observed after $2-3$ days. Isolate HSL6 survived at temperature $15-50^{\circ} \mathrm{C}$ but showed maximum activity at $25^{\circ} \mathrm{C}$. A significant amount of growth at all temperatures can be observed after 2-3 days but growth decreases at $50^{\circ} \mathrm{C}$ after 3 days. Isolate HSL7 showed maximum growth at the temperature range of 15 to $45^{\circ} \mathrm{C}$ but showed maximum activity at $35^{\circ} \mathrm{C}$. Significant growth at all temperatures was observed after 2-3 days (Fig. 3). 


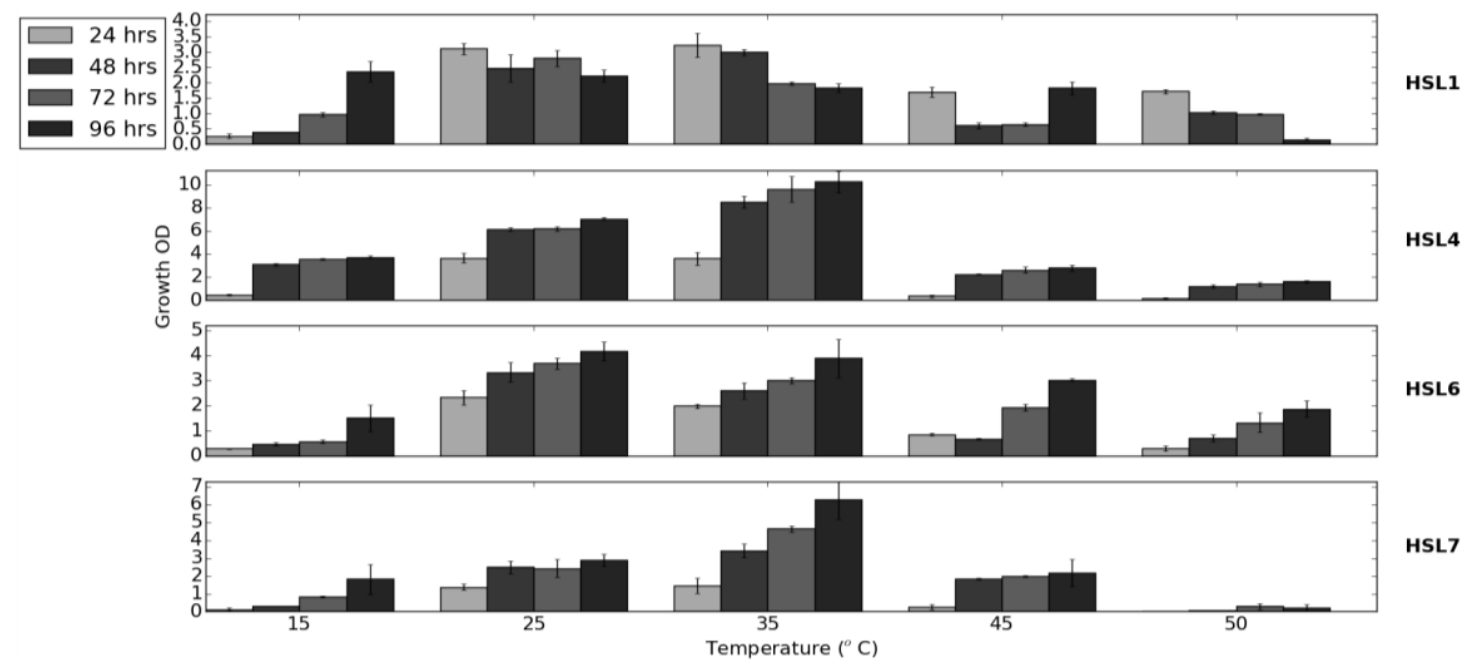

Figure 2. Effect of pH on growth of bacteria

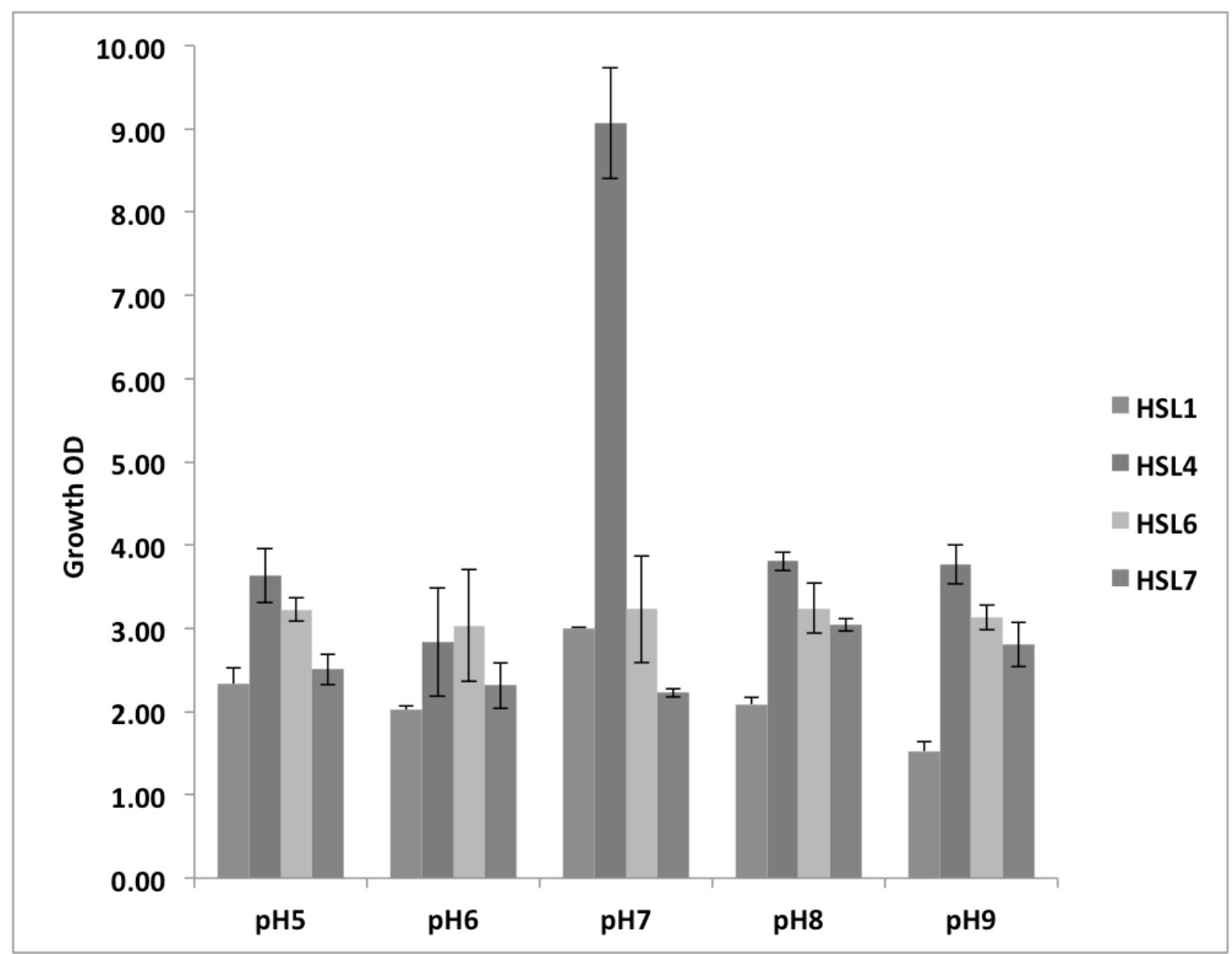

Figure 3. Effect of temperature on growth of bacteria

\section{Quantitative analysis of industrially important enzymes}

Enzyme assays for lipase, protease and amylase were performed to quantitatively measure enzyme activity produced by extremely halophilic bacteria. 


\section{Lipase}

As no clear zone was observed around the cultures grown on a media supplemented with Tween 80, it was assumed that the isolates did not hydrolyze Tween 80 . It is then also confirmed by the quantitative assay. Isolates HSL1, HSL4, HSL6, and HSL7 did not produce lipase enzyme.

\section{Protease}

Isolates HSL4 and HSL7 showed positive results for the production of protease. The specific activity of the enzyme measured by determining the concentration of tyrosine released per ml per min under the assay conditions. It was observed that the production of protease increased with time for three days (Fig. 4a).

\section{Amylase}

The positive results for amylase production were shown by isolate HSL6 and HSL7 qualitatively. Specific activity is determined by measuring the amount of glucose released under the reaction conditions per $\mathrm{ml}$ per min (Fig. 4b).

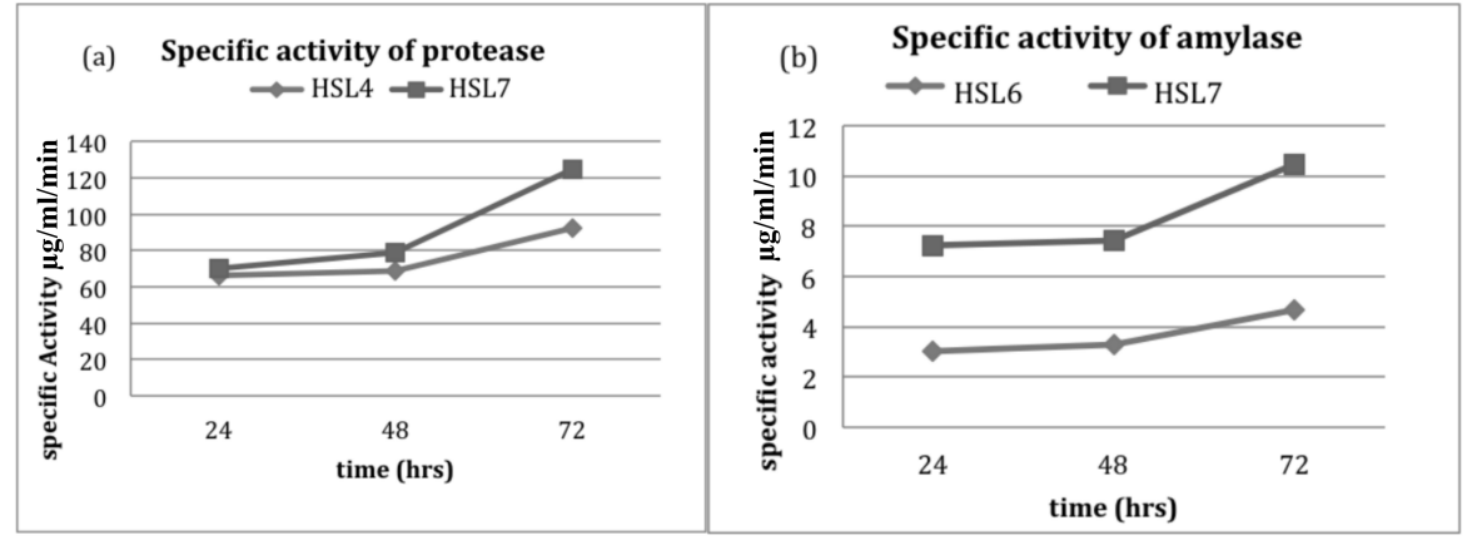

Figure 4. a) Specific activity of amylase. b) Specific activity of protease

\section{Molecular characterization}

The genomic DNA is isolated by a method by Delbes and coworkers (2000). The isolated DNA is confirmed by analyzing DNA with gel electrophoresis with $1 \% \mathrm{Gel}$ in 0.5 X TBE buffer. Gel images were observed by Bio-Rad gel documentation system.

\section{S rRNA sequencing and phylogenetic tree}

According to the BLAST results, HSL1, HSL4, HSL6, and HSL7 showed 99\% identity with Oceanobacillus onchorhynci subsp. Incaldanensis, Staphylococcus lentus. Bacillus endophyticus and Bacillus aquimaris respectively. The partial 16S rRNA were submitted to NCBI. The accession numbers obtained of these strains are the following. KP866216 for HSL1, KP866217 for HSL4, KP866218 for HSL4 and KP866219 for HSL7. The phylogenetic tree reflects the relationship between the halophilic bacterial isolates inferred from the 16S rRNA gene sequence. The bootstrap value is shown at the 
nodes of the phylogenetic tree and is expressed as the percentage of 1000 replications (Fig. 5).

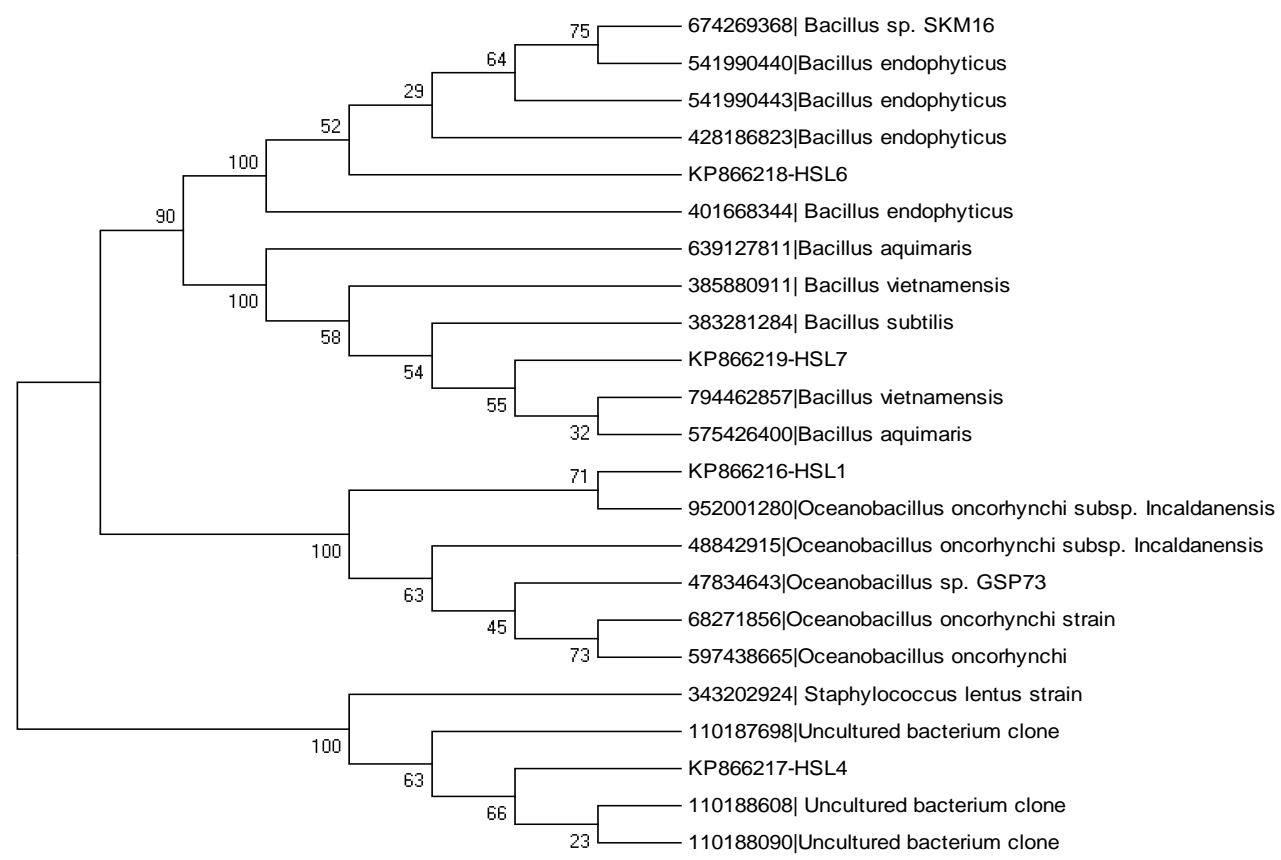

Figure 5. Phylogenetic tree showing the interrelationships between halophilic bacteria and reflecting their evolutionary pattern. The bootstrap value generated as percentage of 1000 replications is shown at the nodes

\section{Discussion}

The present research is focused on the screening and profiling of extremely halophilic bacteria indigenous to Khewra salt range. The isolated bacteria were characterized biochemically and molecularly using 16S rRNA molecular techniques. Furthermore, their different physiological features and their potential biotechnological applications have also been analyzed in this study.

This is the first report that analyzed the tolerance of extremely halophilic bacteria, from Khewra mine, against the salts other than $\mathrm{NaCl}$. The salts used were $\mathrm{KCl}, \mathrm{CaCO}_{3}$, $\mathrm{NH}_{4} \mathrm{Cl}, \mathrm{MgSO}_{4}$, and $\mathrm{BaCl}_{2}$. The media supplemented with $3 \%$ of these salts were used to investigate the tolerance of isolates against these salts. The presence of $\mathrm{Na}^{+} ; \mathrm{K}^{+}$; $\mathrm{Mg}^{2+}$; and $\mathrm{SO}^{2-}$ had been reported previously in the rock salt deposits of Khewra salt mine (Sharif et al., 2007). The analysis of brine samples from Khewra also revealed the presence of $\mathrm{SO}^{2-}, \mathrm{PO}^{3-}, \mathrm{Cl}^{-}$and $\mathrm{CO}_{3}{ }^{2-}$. The values of $\mathrm{Na}^{+} ; \mathrm{K}^{+} ; \mathrm{Ca}^{2+} ; \mathrm{Mg}^{2+} ; \mathrm{Cl}^{-}$and $\mathrm{SO}_{4}{ }^{2-}$ ions in Khewra were comparable to the values investigated in other salt environments as well (Grant et al., 1998). The growth of the isolates in the presence of all these salts highlighted their role in the cycling of various nutrient components. Furthermore, this could lead to valuable insights on the possible ecological role of these extreme halophilic bacteria as they survive under the ecological constraints of the closed environment of Khewra salt mine.

The media used for culturing was nutrient agar, which is rich in nutrients, thus making it suitable for the growth of diversified microbes. The results of the basic characterization highlights diversified colonial morphologies. Both gram-positive and 
gram-negative extremely halophilic bacteria were observed. However, Gram staining procedure may not be very reliable and may prove unsatisfactory in several cases (Duckworth et al., 1996), which could be true for this report as well. One of the isolate HSL1 is a gram-negative rod and shows $99 \%$ resemblance of its 16S rRNA sequence with Oceanobacillus onchorhynchi subsp. Incaldanensis, which was originally reported as Gram-positive rods (Romano et al., 2006). However, colony morphology and biochemical characteristics were found to be similar since both strains displayed beige or off-white colonies. Both were motile and could grow at $20 \%$ of $\mathrm{NaCl}$ concentration. Both showed negative results for, amylase, urease and protease production and positive results for oxidase and catalase reactions. Lipase production of Oceanobacillus onchorhynchi subsp. Incaldanensis has not been reported. HSL1 strain showed negative results for lipase production or hydrolysis of Tween 80 . The major difference between the two strains was in the $\mathrm{pH}$ tolerance of these species. Where Oceanobacillus onchorhynchi subsp. Incaldanensis could only survive at pH 6-9 (Optimum pH 9.0), strain HSL1 could grow at $\mathrm{pH}$ ranging from 5 to 9 with optimum growth at $\mathrm{pH} 7$. The temperature range for Oceanobacillus onchorhynchi subsp. Incaldanensis was reported between 10 and $40^{\circ} \mathrm{C}$ but HSL1 can survive even at $45^{\circ} \mathrm{C}$ (Romano et al., 2006). The difference of Gram-staining and physiological attributes between Oceanobacillus onchorhynchi subsp. Incaldanensis and HSL1 allowed us to tentatively assume that HSL1 might be a different strain of the same species.

Isolate HSL4 showed 99\% resemblance of its 16S rRNA sequence with Staphylococcus lentus. According to our study, the basic identification features of the two strains were quite similar morphologically. However, the biochemical and physiological parameters of HSL4 and Staphylococcus lentus showed some variations. HSL4 was extremely halophilic and could grow at $\mathrm{NaCl}$ concentration up to $22 \%$ whereas Staphylococcus lentus has been reported as moderately halophilic. The temperature stability of the two strains was also different, as HSL4 could tolerate temperatures ranging from 15 to $45^{\circ} \mathrm{C}$, whereas Staphylococcus lentus showed no growth at $15^{\circ} \mathrm{C}$ and $45^{\circ} \mathrm{C}$ (Schleifer et al., 1983). Biochemical tests also showed considerable variations. Staphylococcus lentus was positive for oxidase, gelatinase, and DNase tests, whereas HSL4 was negative for all these tests. It can be deducted from the above results that HSL4 strain resembled very closely to Staphylococcus lentus on the basis 16S rRNA sequence. However, HSL4 strain was quite distinct from Staphylococcus lentus on the basis of physiology and biochemical characteristics, therefore rendering HSL4 a different strain of Staphylococci genus having more diverse range for growth as described for other strains of Staphylococci (Graham and Wilkinson, 1992; Morikawa et al., 2010).

HSL6 was also identified as a gram-positive bacillus and showed 99\% sequence similarity with Bacillus endophyticus discovered by Reva and coworkers (2002). The morphology and biochemical characteristics of the HSL6 were found to be quite similar to Bacillus endophyticus. The difference between the two could be found in their ability to hydrolyze starch. Bacillus endophyticus was reported to show a negative result for amylase production (Reva et al., 2002), whereas strain HSL6 was able to produce a substantial amount of amylase. Conclusively, strain HSL6 was identified as Bacillus endophyticus.

Strain HSL7 showed a maximum resemblance of its $16 \mathrm{~S}$ rRNA with two species. Bacillus subtilis (99\%) and Bacillus aquimaris (99\%). However, based on the colony morphology, physiology, and biochemical characteristics, Bacillus subtilis was 
completely ruled out. HSL7 strain shared most of its characteristics with Bacillus aquimaris. Both were gram-positive rods, motile and had orange mucoid, circular colonies. This strain was positive for the production of protease, amylase, and catalase and negative for urease, gelatinase, and oxidase and indole production. All these characteristics were also true for Bacillus aquimaris which was isolated from the tidal flat of Yellow sea, Korea (Yoon et al., 2003). However, the physiological attributes of HSL7 strain and Bacillus aquimaris were slightly different. Though both were extremely halophilic and could survive at $\mathrm{NaCl}$ concentration up to $18 \%$, they also showed variations in physiology. HSL7 grew best at $\mathrm{pH} 8$ and survived at $\mathrm{pH}$ ranging from 5 to 9 . The growth of HSL7 was also observed at $45^{\circ} \mathrm{C}$ temperature. Contrary to this, Bacillus aquimaris was reported to have an optimum growth at $\mathrm{pH} 7$ and could not survive at $\mathrm{pH} 5$ or 9 . It also showed no growth at temperature $45^{\circ} \mathrm{C}$. These differences in the growth pattern of HSL7 and Bacillus aquimaris might have arisen due to their adaptations to various habitats from which they had been isolated. Due to maximum similarities between the HSL1 and Bacillus aquimaris strains, HSL7 was identified as Bacillus aquimaris.

In the present study HSL1-Oceanobacillus onchorhynci subsp. Incaldanensis, HSL4Staphylococcus lentus, HSL6-Bacillus endophyticus and HSL7-Bacillus aquimaris were found to be efficient producers of commercially important enzymes with tremendous potential for commercial exploitation. Their wide range of tolerance to salt, temperature, and $\mathrm{pH}$ is because of the stability of their enzymes making them very useful in industry. Enzymes assays revealed, a substantial amount of enzyme production from these strains such as protease, amylase, lipase, xylanase, urease, gelatinase, cellulase and DNase.

\section{Conclusion}

Conclusively, this report filled a gap in addressing the prokaryotic halophilic diversity by isolation of the extremely halophilic bacteria from the salt mines of Khewra, Pakistan. The rich diversity of Bacillus in the salt deposits is consistent with the other reports of halophiles from salt mines around the globe, and highlight their extensive role in maintaining the ecosystem (Rohban et al., 2009; Roohi et al., 2014). Moreover, some reports suggested bacillus species to be ideal for the production of industrially important enzymes due to the short duration of fermentation cycle, accelerated growth rates and capability to produce extracellular enzymes (Schallmey et al., 2004). Since most strains studied in this research are bacilli, the enzymes produced from these species can be expected to have significant potential ensuring high yield, increased stability and reliability; thus, making these enzymes commercially very important. The isolates revealed unique biotechnological applications by producing a substantial amount of amylase and protease as well as screening positive for xylanase, urease, gelatinase, cellulase, and DNase. The isolated bacteria are poly-extremophile with an ability to survive in a wide range of $\mathrm{pH}$, temperature, and salinity.

\section{Future Prospects}

Khewra salt mine has proven to be a vital ecological niche supporting the survival of a diverse range of microorganisms, and little is known about extreme-enzymes produced by rock salt microbiota. To answer the fascinating question of their adaptations leading to their long-term survival within the salt crystals, diversity analysis 
should be conducted by combining the culture-dependent and culture-independent techniques using sophisticated technologies such as Next-Generation Sequencing. This would aid in understanding the entire community profile and the interactions among the community in the hypersaline environment. Such insights would lead to possible exploitation of early evolutionary and extraterrestrial life and environment (Bowers et al., 2009). To further exploit the stability of halo-enzymes for production in commercial applications, more investigations should be directed towards the characterization of the enzymes at multiple concentrations of salinities, temperature, and $\mathrm{pH}$. Future studies should also be directed towards the corresponding encoding genes for adaptations in high salinity, to further analyze the use of these extreme-enzymes in large-scale industrial processes.

\section{REFERENCES}

[1] Akhtar, N., Ghauri, M. A., Iqbal, A., Anwar, M. A., Akhtar, K. (2008): Biodiversity and phylogenetic analysis of culturable bacteria indigenous to Khewra salt mine of Pakistan and their industrial importance. - Braz J Microbiol 39: 143-150.

[2] Bowers, K. J., Mesbah, N. M., Wiegel, J. (2009): Biodiversity of poly-extremophilic bacteria: Does combining the extremes of high salt, alkaline $\mathrm{pH}$ and elevated temperature approach a physico-chemical boundary for life. - Saline Syst 5: 9-17

[3] Burg, B. (2003): Extremophiles as a source for novel enzymes. - Curr Opin Microbiol 6: 213-218.

[4] Cojoc, R., Merciu, S., Popescu, G., Dumitru, L., Kamekura, M., Enache, M. (2009): Extracellular hydrolytic enzymes of halophilic bacteria isolated from a subterranean rock salt crystal. - Rom Biotechnol Lett 14: 4658-4664.

[5] Donio, M. B. S., Ronica, F. A., Viji, V. T., Velmurugan, S., Jenifer, J. S. C. A., Michaelbabu, M. V., Prasenjit, D. P., Citarasu, T. (2013): Halomonas sp. BS4. A biosurfactant producing halophilic bacterium isolated from solar salt works in India and their biomedical importance. - Springerplus 2: 149

[6] Delbes, C., Moletta, R., Godon, J. J. (2000): Monitoring of activity dynamics of an anaerobic digester bacterial community using 16S rRNA PCR-Single-Strand Conformation Polymorphism analysis (SSCP). - Environ Microbiol 5: 506-515.

[7] Duckworth, A. W., Grant, W. D., Jones, B. E., Steenbergen, R. V. (1996): Phylogenetic diversity of soda lake alkaliphiles. - FEMS Microbiol Ecol 19: 181-191.

[8] Graham, J. E., Wilkinson, B. J. (1992): Staphylococcus aureus osmoregulation: roles for choline, glycine betaine, proline, and taurine. - J Bacteriol 174: 2711-2716.

[9] Grant, W. D., Gemmell, R. T., Mcgenity, T. J. (1998): Halophiles. - In: Horikoshi, K., Grant, W. D. (eds.) Extremophiles, pp. 93-132. Wiley-Liss, New York.

[10] Holt, J. G., Krieg, N. R., Sneath, P. H., Staley, J. T., Williams, S. T. (1994): Bergey's Manual of Determinative Bacteriology, pp. 39-63. - Williams and Wilkins, Baltimore.

[11] Husseini, M. I., Husseini, S. I. (1990): Origin of the Infracambrian salt basins of the Middle East. - Geological Society, London, Special Publications 50(1): 279-292.

[12] Kunitz, N. (1965): Methods of Enzymatic Analysis ( $2^{\text {nd }}$ ed). - Verlag Chem, pp. 807-814. Academic Press, New York, London.

[13] Kushner, D. J. (1978): Life in High Salt and Solute Concentrations. - In: Kushner, D. J. (ed.) Microbial Life in Extreme Environments, pp. 317-368. Academic Press, London.

[14] Kushner, D. J. (1985): The Halobacteriaceae. - In: Woese, C. R., Wolfe, R. S. (eds.) The Bacteria. Vol. 8, pp. 171-214. Academic Press, Orlando.

[15] Lesuisse, E., Schanck, K., Colson, C. (1993): Purification and preliminary characterization of the extracellular lipase of Bacillus subtilis 168, an extremely basic $\mathrm{pH}$ tolerant enzyme. - Eur J Biochem 216: 155-160. 
[16] Kakhki, A. M., Amoozegar, M. A., Khaledi, E. M. (2011): Diversity of hydrolytic enzymes in haloarchaeal strains isolated from Salt Lake. - Int J Environ Sci Technol 8(4): 705-714.

[17] Morikawa, K., Ohniwa, R. L., Ohta, T., Tanaka, Y., Takeyasu, K., Msadek, T. (2010): Adaptation beyond the stress response: Cell structure dynamics and population heterogeneity in Staphylococcus aureus. - Microb Environ 25: 75-82.

[18] Oren, A. (2008): Microbial life at high salt concentrations: phylogenetic and metabolic diversity. - Saline Systems 4: 2.

[19] Redfern, R. (2001): Origins: The Evolution of Continents, Oceans, and Life. - University of Oklahoma Press, Norman.

[20] Reva, O. N., Smirnov, V. V., Pettersson, B., Priest, F. G. (2002): Bacillus endophyticus sp. nov., isolated from the inner tissues of cotton plants (Gossypium sp). - Int J Sys Evo Microbiol 52(1): 101-107.

[21] Rohban, R., Amoozegar, M. A., Ventosa, A. (2009): Screening and isolation of halophilic bacteria producing extracellular hydrolyses from Howz Soltan Lake, Iran. - Ind J Microbiol Biotechnol 36: 333-340.

[22] Roohi, A., Ahmed, I., Paek, J., Sin, Y., Abbas, S., Jamil, M., Chang, Y. H. (2014): Bacillus pakistanensis sp. nov., a halotolerant bacterium isolated from salt mines of the Karak Area in Pakistan. - Antonie Leeuwenhoek 105:1163-1172.

[23] Romano, I., Lama, L., Nicolaus, B. (2006): Oceanobacillus oncorhynchi subsp. incaldanensis subsp. nov., an alkalitolerant halophile isolated from an algal mat collected from a sulfurous spring in Campania (Italy), and emended description of Oceanobacillus oncorhynchi. - Int J Sys Evo Microbiol 56: 805-810.

[24] Sameeni, S. J. (2009): The Salt Range: Pakistan's Unique Field Museum of Geology and Paleontology. - In: Lipps, J. H., Granier, B. R. C. (eds.) PaleoParks - The Protection and Conservation of Fossil Sites Worldwide, Book 3, Chapter 6. Carnets de Géologie/Notebooks on Geology, Brest.

[25] Schallmey, M., Singh, A., Ward, O. P. (2004): Developments in the use of Bacillus species for industrial production. - Can J Microbiol 50(1): 1-17.

[26] Schleifer, K. H., Geyer, U., Kilpper-Bälz, B.R., Devriese, L. A. (1983): Elevation of Staphylococcus sciuri subsp lentus to species status: Staphylococcus lentus (Kloos et al.) combnov. - Syst Appl Microbiol 4: 382-387.

[27] Tatusova, T. A., Madden, T. L. (1999): BLAST 2 Sequences, a new tool for comparing protein and nucleotide sequences. - FEMS Microbiol Lett 174: 247-250

[28] Thompson, J. D., Higgins, D. G., Gibson, T. J. (1994): CLUSTAL W: improving the sensitivity of progressive multiple sequence alignment through sequence weighting, position-specific gap penalties and weight matrix choice. - Nucleic Acids Res 22(22): 4673-4680.

[29] Vahed, Z. S., Forouhandeh, H., Hassanzadeh, S., Klenk, H., Hejazi, M. A., Hejazi, M. S. (2011): Isolation and characterization of halophilic bacteria from Urmia Lake in Iran. Mikrobiologiia 80(6): 826-33.

[30] Yoon, J., Kim, I., Kang, K. H. (2003): Bacillus marisflavi sp. nov. and Bacillus aquimaris sp. nov., isolated from sea water of a tidal flat of the Yellow Sea in Korea. - Int J Sys Evo Microbiol 53: 1297-1303.

[31] Bernfeld, P. (1955): Amylases, alpha and beta. - Meth Enzymo 1: 149-158. 